\title{
BIOTYPING, SEROTYPING AND RIBOTYPING AS EPIDEMIOLOGICAL TOOLS IN THE EVALUATION OF Acinetobacter baumannii DISSEMINATION IN HOSPITAL UNITS, SOROCABA, SÃO PAULO, BRAZIL
}

Célia R. GONÇALVES(1), Tania Mara I.VAZ(1), Eliane ARAUJO(2), Regina de Fátima BONI(2), Daniela LEITE(1) \& Kinue IRINO(1)

\begin{abstract}
SUMMARY
Dissemination of Acinetobacter baumannii strains in different units of a hospital in Sorocaba, São Paulo, Brazil was evaluated over a period of two years. By using biotyping, serotyping and ribotyping, 27 distinct clones were differentiated among 76 strains isolated between 1993-94, from clinical specimens of hospitalized patients. Two clones, 2:04:A (biotype:serotype:ribotype) and 2:O29:A accounted for the majority of strains widely disseminated in the units during 1993. The introduction in the hospital setting, of a new clone, 6:O13:B, at the end of 1993 and its predominance through 1994 is discussed. Among 15 strains isolated from neonates, $6(40 \%)$ belonged to the same clone, 2:O4:A. Interestingly, this clone was almost all recovered in neonatal intensive care unit, nursery and in pediatric unit. All strains were susceptible to imipenem and polymyxcin B. Multiresistant strains (up to 12 antimicrobial agents) accounted for $66.7 \%$ and $84.8 \%$ of the strains isolated in 1993 and in 1994, respectively.
\end{abstract}

KEYWORDS: Acinetobacter baumannii; Biotyping; Serotyping; Ribotyping; Multiresistance.

\section{INTRODUCTION}

Among 21 genomic species recognized within the genus Acinetobacter ${ }^{5,7,12,27}$, Acinetobacter baumannii has been found most frequently associated with outbreaks of nosocomial infections ${ }^{2,4,6,24}$ although other species like Acinetobacter genomic species 3 and 13 have also been implicated ${ }^{5,6}$. A number of factors as immunosuppresion, age, surgery, underlying diseases, use of invasive devices and antimicrobial agents etc, have been reported as increasing the risk of infection or colonization by these opportunistic pathogens ${ }^{3,16,26}$.

The emergence and increase of antibiotic multiply-resistant strains of $A$. baumannii ${ }^{2,13,23,31}$ and the remarkable capacity of long-term survival in hospital environment which favors their spreading, represent a serious challenge in infection control.

The natural habitat of $A$. baumannii remains still unknown ${ }^{25}$. Although this microorganism is the most frequently implicated genomic species in hospital infections, it is rarely found in human skin in contrast to other Acinetobacter species which can form part of the normal bacterial flora of $\operatorname{skin}^{1,25}$.

Persistence of epidemic strains of Acinetobacter on equipment or other materials of hospital units, even after the discharge of colonized patients, probably is responsible for long-term outbreaks and for the occurrence of endemic nosocomial infections in patients of many units.
The purpose of this study was to characterize phenotypically and genotypically A. baumannii strains isolated from patients hospitalized in different medical care units between 1993-94 and to evaluate the dissemination of particular clones through the hospital units.

\section{MATERIAL AND METHODS}

Bacterial strains. A total of 76 strains of A. baumannii isolated between 1993-94 were studied. These strains were isolated from patients hospitalized in different units of a general hospital in Sorocaba, São Paulo State, Brazil. Forty four strains were from secretions (respiratory tract, wounds, surgical wounds), 14 from catheter tip, 6 from effluent filter, 6 from blood, 4 from urine, and 2 from pleural fluid. All strains were identified as A. baumannii according to BOUVET \& GRIMONT $^{5}$ in the Regional Laboratory of Sorocaba and sent to the Central Laboratory for further characterization.

Biotyping and serotyping. All strains were biotyped following the method described by BOUVET \& GRIMONT ${ }^{6}$ using levulinate, citraconate, L-phenylalanine, phenylacetate, 4-hydroxybenzoate and Ltartarate in carbon source utilization test. Serotypes were determined using $34 \mathrm{O}$-antisera prepared with reference strains of A. baumannii. Tube agglutination test was done according to TRAUB ${ }^{28}$ with minor modifications $^{19,29}$.

Antimicrobial susceptibility test. Antimicrobial resistance patterns

(1) Instituto Adolfo Lutz, São Paulo, SP, Brazil.

(2) Instituto Adolfo Lutz, Sorocaba, São Paulo, Brazil.

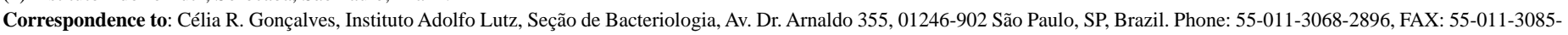
3505. E-mail: celiargc@hotmail.com 


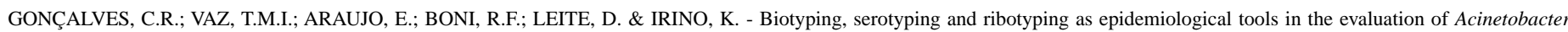
baumannii dissemination in hospital units, Sorocaba, São Paulo, Brazil. Rev. Inst. Med. trop. S. Paulo, 42(5): 277-282, 2000.

were determined by using agar diffusion method according to the National Committee for Clinical Laboratory Standards ${ }^{17}$ for susceptibility to cefotaxime $(30 \mu \mathrm{g})$, ceftazidime $(30 \mu \mathrm{g})$, imipenem $(15 \mu \mathrm{g})$, ampicillin $(33 \mu \mathrm{g})$, ticarcillin/clavulanic acid $(75 / 10 \mu \mathrm{g})$, gentamicin $(10 \mu \mathrm{g})$, tetracycline $(80 \mu \mathrm{g})$, sulfamethoxazole/trimethoprim $(25 \mu \mathrm{g})$, amikacin $(30 \mu \mathrm{g})$, ciprofloxacin $(5 \mu \mathrm{g})$, tobramycin $(10 \mu \mathrm{g})$, netilmicin $(30 \mu \mathrm{g})$, polymyxin B (300 IU), streptomycin $(10 \mu \mathrm{g})$, kanamycin $(30 \mu \mathrm{g})$. All antimicrobial drugs were from Cecon - Centro de Controle e Produtos para Diagnóstico Ltda, São Paulo, Brazil. Pseudomonas aeruginosa ATCC 27853, Escherichia coli ATCC 25922, Staphylococcus aureus ATCC 25923, and E. faecalis ATCC 29212 were used as control strains.

Ribotyping. All strains were ribotyped. Bacterial DNA was extracted as described elsewhere ${ }^{9}$. Five $\mu \mathrm{g}$ of DNA samples were digested with EcoRI following the instructions of the manufacturer (Pharmacia-LKB). After agarose gel electrophoresis, the fragments were transferred to nylon membranes using a vacuum blotter (Vacugen, Pharmacia-LKB) with 20xSSC as the transfer solution. Membranes were hybridized with a digoxigenin-11-dUTP-labelled cDNA probe derived from $E$. coli $16+23 \mathrm{~S}$ rRNA prepared by random priming using reverse transcriptase. Hybridization conditions were essentially as described by POPOVIC et al. ${ }^{20}$. H. aegyptius 3031 EcoRI DNA digest (fragments of 1.5 to 17.6 $\mathrm{kb}$ ) was used as molecular marker. Fragment sizes were estimated using a computer program (DNASTAR Computer System for Molecular Biology and Genetics, London, UK) and capital letters were used to identify the ribotypes. In order to confirm the distinct ribotypes obtained after digestion with EcoRI, DNA samples of representative strains of each ribotype were clived with a second enzyme HindIII.

\section{RESULTS}

Biotyping and serotyping. Overall two biotypes, biotype 2 and biotype 6 , accounted for $85.5 \%$ of strains. Biotype $2(63.8 \%)$ predominated among strains isolated in 1993, whereas biotype $6(62.5 \%)$ strains were the most frequent in 1994 followed by biotype 2 strains (37.5\%). Serotyping was more discriminatory than biotyping. Among 76 strains, $63(82.9 \%)$ were typable and 12 serotypes were encountered. Four serotypes, O29 (26.3\%), O13 (21.0\%), O4 (10.5\%) and O11 (7.9\%), predominated in our sample (Table 1).

Antimicrobial susceptibility test. Of 30 strains isolated in 1993, $6.7 \%$ were susceptible to all tested drugs while $66.7 \%$ were multipleresistant to more than 4 and up to 12 antimicrobial drugs. Of the 46 strains recovered in 1994, $4.3 \%$ were susceptible to all antimicrobials and $84.8 \%$ were multiple resistant up to 12 tested drugs. In Table 3 are listed all the antimicrobial resistance patterns seen in the four predominant clones (2:O29:A, 2:O4:A, 2:O11:A, and 6:O13:B) isolated during 199394.

Ribotyping. Thirteen distinct ribotypes arbitrarily named A to $\mathrm{M}$ were obtained after DNA digestion with EcoRI. Two ribotypes, A (52.6\%) and B $(27.6 \%)$ predominated among 76 strains. The banding patterns in the blot of representative ribotypes are shown in Fig. 1. Fig. 1a shows 12 of 13 banding patterns found among our strains when digested with EcoRI. Ribotype $\mathrm{G}$ is not shown because of its incomplete digestion in this blot. EcoRI was more discriminatory than HindIII as we can see in Fig.1b, where ribotypes D and E displayed the same banding pattern after digestion with HindIII.
Combination of typing results. By combining the results obtained with biotyping, serotyping and ribotyping, 27 clones were distinguished among 76 strains. Four clones, 2:O4:A, 2:O11:A, 2:O29:A, and 6:O13:B, were the most frequently recovered ones in different hospital units. The majority of strains of biotype 2, irrespective of the serotype were associated with ribotype A. On the other hand, $77 \%$ of strains belonging to biotype 6 were related to ribotype B. The distribution of all clones according to the care units is shown in Table 2. Clones characterized as 2:O4:A and 2:O29:A predominated among strains isolated in 1993, whereas strains belonging to clone 6:O13:B were the most frequent in 1994. All strains belonging to biotype 2 and to serotype O29 were ribotype A. On the other hand all strains of biotype 6 and serotype $\mathrm{O} 13$ were ribotype B. No specific antimicrobial resistance patterns were associated with distinct clones. Distinct antimicrobial resistance patterns associated with the main clones are shown in Table 3.

Table 1

Annual distribution of A. baumannii clones characterized by the association of biotype, serotype and ribotype

\begin{tabular}{|c|c|c|c|}
\hline $\begin{array}{c}\text { Clones } \\
\text { (Biotype/Serotype/Ribotype) }\end{array}$ & 1993 & 1994 & Total of strains \\
\hline 2/O4/A & 6 & 2 & 8 \\
\hline 2/O11/A & - & 5 & 5 \\
\hline 2/O13/C & 1 & - & 1 \\
\hline 2/O15/D & - & 1 & 1 \\
\hline 2/O28/A & - & 1 & 1 \\
\hline 2/O29/A & 14 & 4 & 18 \\
\hline 2/O32/A & - & 1 & 1 \\
\hline 2/ONT/A & 2 & 1 & 3 \\
\hline $5 / \mathrm{O} 1 / \mathrm{L}$ & - & 1 & 1 \\
\hline 6/O1/B & - & 1 & 1 \\
\hline 6/O13/B & 1 & 13 & 14 \\
\hline 6/O13/M & 1 & - & 1 \\
\hline 6/O15/D & - & 1 & 1 \\
\hline 6/O19/E & - & 1 & 1 \\
\hline 6/O32/B & - & 3 & 3 \\
\hline 6/ONT/B & - & 3 & 3 \\
\hline 6/ONT/D & - & 2 & 2 \\
\hline 6/O29/A & - & 1 & 1 \\
\hline $8 / \mathrm{O} 7,14 / \mathrm{J}$ & 1 & - & 1 \\
\hline 8/O11/I & 1 & - & 1 \\
\hline 8/ONT/A & 1 & - & 1 \\
\hline 9/O30/A & 1 & 1 & 2 \\
\hline 9/'R"'/G & 1 & - & 1 \\
\hline 9/ONT/A & 1 & - & 1 \\
\hline 9/ONT/H & - & 1 & 1 \\
\hline $11 / \mathrm{ONT} / \mathrm{F}$ & - & 1 & 1 \\
\hline $\mathrm{Nd} / \mathrm{O} 29 / \mathrm{K}$ & 1 & & 1 \\
\hline Total & 32 & 44 & 76 \\
\hline
\end{tabular}

"R", rough strain; ONT, non-typable with 34 O-antisera; Nd/O29/K, biotype not determined. 

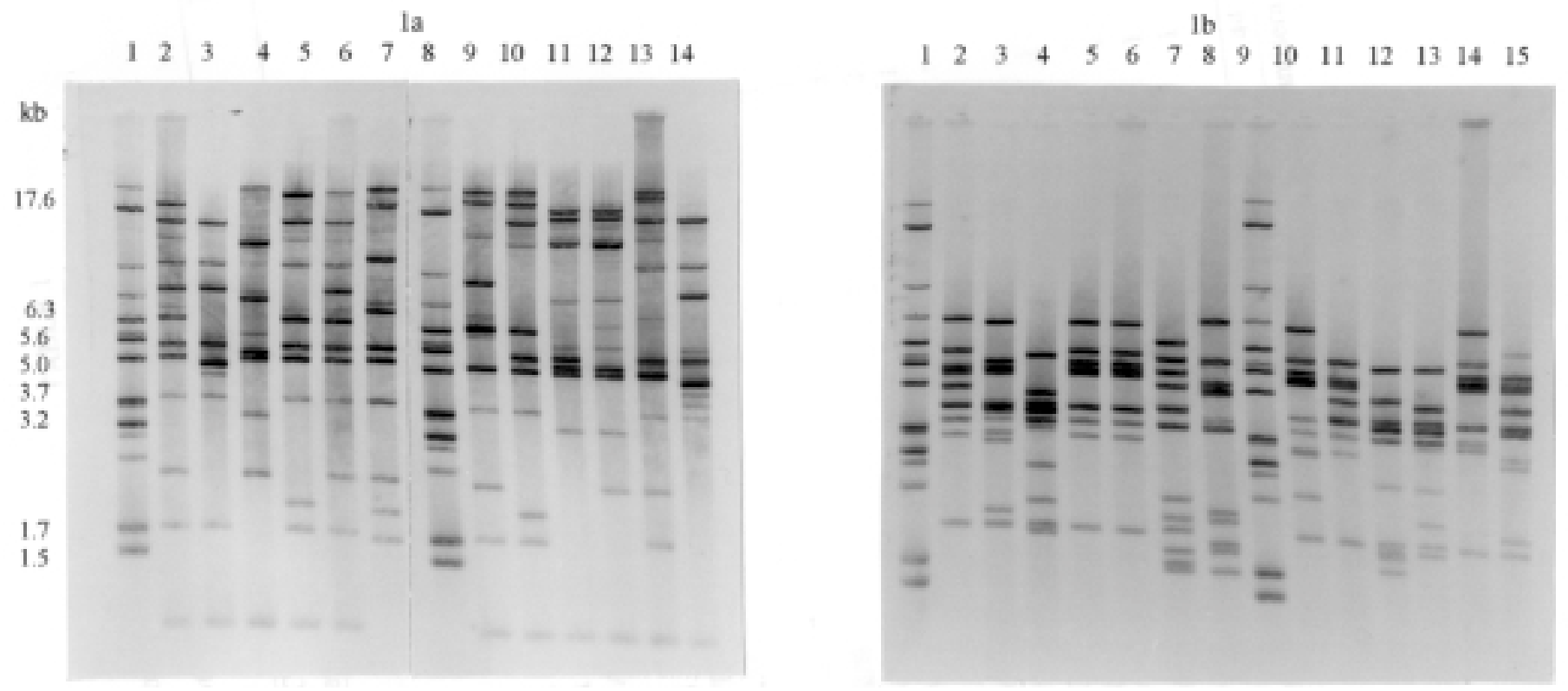

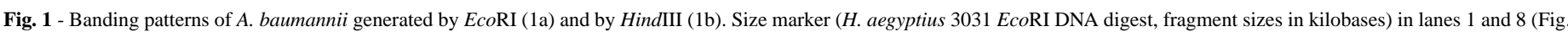

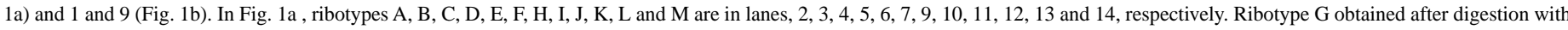

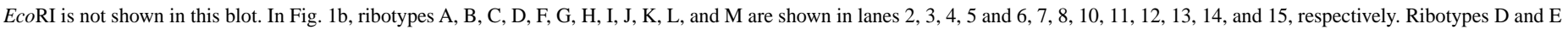
obtained after digestion with EcoRI displayed the same profile when clived with HindIII (lanes 5 and 6 of Fig. 1b).

Table 2

Distribution according to the hospital units of A. baumannii clones characterized by the association of biotype:serotype:ribotype isolated between 1993-94

\begin{tabular}{|c|c|c|c|c|c|c|c|c|c|c|c|}
\hline \multicolumn{12}{|c|}{ A. baumannii clones } \\
\hline Units & 2:O4:A & 2:011:A & 2:O29:A & 2:Od:Rd & 5:O1:R & $6: 013: B$ & 6:Od:Rd & 8:Od:Rd & 9:Od:Rd & 11:ONT:H & Nd:O29:K \\
\hline NICU & 3 & & & 1 & & & 1 & 1 & 1 & & 1 \\
\hline AICU & & 1 & 4 & 2 & & 1 & 1 & & & & \\
\hline $\mathrm{BN}$ & 3 & & & & & & & & 1 & & \\
\hline PED & 1 & & & & & 2 & & 1 & 1 & & \\
\hline GM & & 1 & 1 & 1 & & & & & & & \\
\hline $\mathrm{NPH}$ & & 1 & 1 & 1 & & 3 & 4 & 1 & & & \\
\hline PN & & & & 1 & & 1 & & & & & \\
\hline $\mathrm{CV}$ & 1 & & 1 & & & & 1 & & 1 & & \\
\hline END & & & 1 & & & & & & & & \\
\hline GS & & & 4 & & 1 & 2 & & & & & \\
\hline ONC & & & 1 & & & & & & & & \\
\hline THOR & & & 1 & & & & 1 & & 1 & & \\
\hline URO & & & & & & & 1 & & & & \\
\hline ORT & & & 1 & & & 1 & 1 & & & & \\
\hline NEU & & & & 1 & & 1 & & & & & \\
\hline UNK & & 2 & 3 & & & 3 & 3 & & & 1 & \\
\hline Total & 8 & 5 & 18 & 7 & 1 & 14 & 13 & 3 & 5 & 1 & 1 \\
\hline
\end{tabular}

2:Od:Rd = biotype 2: different serotypes $(\mathrm{O} 13 ; \mathrm{O} 15 ; \mathrm{O} 28 ; \mathrm{O} 32 ; \mathrm{ONT})$ : different ribotypes $(\mathrm{A} ; \mathrm{C} ; \mathrm{D}) ; 6: \mathrm{Od}: \mathrm{Rd}=$ biotype 6: different serotypes

$(\mathrm{O} 1 ; \mathrm{O} 13 ; \mathrm{O} 15 ; \mathrm{O} 19 ; \mathrm{O} 29 ; \mathrm{O} 32 ; \mathrm{ONT})$ : different ribotypes $(\mathrm{A} ; \mathrm{B} ; \mathrm{D} ; \mathrm{E} ; \mathrm{M}) ; 8: \mathrm{Od}: \mathrm{Rd}=$ biotype 8 : different serotypes $(\mathrm{O} 7,14 ; \mathrm{O} 11 ; \mathrm{ONT})$ : different ribotypes $(\mathrm{A} ; \mathrm{J} ; \mathrm{I})$; 9:Od:Rd = biotype 9: different serotypes (O30;ONT): different ribotypes (A;G;H) Nd:O29:K (biotype not determined/serotype O29/ribotype K); Units - NICU (neonatal intensive care unit); AICU (adult intensive care unit); BN (nursery); PED (pediatric); GM (general medicine); NPH (nephrology); PN (pulmonary); CV (cardiovascular); END (endocrinology); GS (general surgery); ONC (oncology); THOR (thoracic); URO (urology); ORT (orthopedic); NEU (neurology); UNK (unknown). 


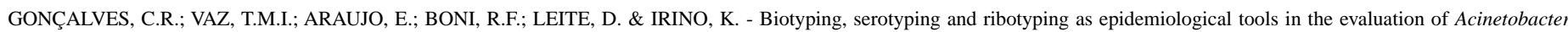
baumannii dissemination in hospital units, Sorocaba, São Paulo, Brazil. Rev. Inst. Med. trop. S. Paulo, 42(5): 277-282, 2000.

Table 3

Antimicrobial resistance patterns of four main clones of Acinetobacter baumannii isolated during the period 1993-94

\begin{tabular}{|c|c|c|c|c|}
\hline Clone & Total of Strains & Unit & Year of Isolation & Antimicrobial Resistance Patterns \\
\hline \multirow[t]{7}{*}{ 2:O4:A } & 1 & NICU & 1993 & ET \\
\hline & 1 & PED & 1993 & AM AP CIP CTX ET GN KN SFT TB TT \\
\hline & 1 & NICU & 1993 & AM AP CAZ CIP CTX GN ET KN SFT TB TIC TT \\
\hline & 2 & NICU/BN & 1993 & AM AP CAZ CTX ET GN KN SFT TB \\
\hline & 1 & $\mathrm{CV}$ & 1994 & AM AP CAZ CIP CTX ET KN SFT TIC \\
\hline & 1 & $\mathrm{BN}$ & 1993 & AM AP CAZ CTX ET GN KN SFT TB TIC \\
\hline & 1 & $\mathrm{BN}$ & 1993 & AM AP CAZ CIP CTX ET GN KN SFT TB TIC TT \\
\hline \multirow[t]{4}{*}{ 2:O11:A } & 1 & GM & 1994 & AM AP CAZ CTX ET KN SFT \\
\hline & 2 & NPH/UNK & 1994 & AM AP CAZ CIP CTX ET KN SFT TT \\
\hline & 1 & AICU & 1994 & AM AP CAZ CIP CTX ET GN KN SFT TIC TT \\
\hline & 1 & UKN & 1994 & AM AP CAZ CIP CTX ET GN KN SFT TB TT \\
\hline \multirow[t]{13}{*}{ 2:O29:A } & 1 & UNK & 1993 & AP TT \\
\hline & 1 & UNK & 1994 & AM AP ET KN SFT \\
\hline & 2 & NPH/AICU & 1993 & AM AP CTX ET KN SFT \\
\hline & 2 & AICU/CV & 1993 & AM AP CAZ CTX ET KN SFT \\
\hline & 1 & THOR & 1993 & AM AP CTX ET KN SFT TT \\
\hline & 2 & GS/AICU & 1993 & AM AP CAZ CTX ET KN SFT TIC \\
\hline & 1 & ONC & 1993 & AM AP CTX ET GN KN SFT TB \\
\hline & 2 & GS/END & 1993 & AM AP CAZ CTX ET KN SFT TT \\
\hline & 2 & GS/ORT & 1993-94 & AM AP CAZ CTX ET GN KN SFT TB \\
\hline & 1 & UNK & 1993 & AM AP CAZ CTX ET GN KN SFT TIC TT \\
\hline & 1 & AICU & 1994 & AM AP CAZ CTX ET GN KN SFT TB TIC \\
\hline & 1 & GM & 1994 & AM AP CAZ CTX ET GN KN SFT TB TT \\
\hline & 1 & GS & 1994 & AM AP CAZ CTX ET GN KN SFT TIC TB TT \\
\hline \multirow[t]{14}{*}{ 6:013:B } & 1 & PED & 1994 & AP \\
\hline & 1 & $\mathrm{NPH}$ & 1994 & AM GN NET TB \\
\hline & 1 & UNK & 1994 & AP CAZ CTX KN NET \\
\hline & 1 & $\mathrm{NPH}$ & 1994 & CAZ CTX KN NET TB \\
\hline & 1 & $\mathrm{NPH}$ & 1994 & AP CAZ CTX KN NET TB \\
\hline & 1 & AICU & 1994 & AM AP CIP CTX KN NET TB \\
\hline & 1 & NEU & 1994 & AM AP CTX ET KN NET TB \\
\hline & 1 & UNK & 1994 & AM AP CAZ CTX ET GN KN NET TB \\
\hline & 1 & GS & 1994 & AM AP ET GN KN NET SFT TB TT \\
\hline & 1 & $\mathrm{PN}$ & 1994 & AP CTX GN ET KN NET SFT TB TIC TT \\
\hline & 1 & GS & 1994 & AM AP CAZ CTX ET GN KN NET TB TT \\
\hline & 1 & ORT & 1994 & AM AP CTX ET KN NET SFT TB TIC TT \\
\hline & 1 & PED & 1993 & AM AP CAZ CTX GN KN NET SFT TB TIC TT \\
\hline & 1 & UNK & 1994 & AM AP CAZ CTX ET GN KN NET SFT TB TIC TT \\
\hline
\end{tabular}

Amikacin (AM); Ampicillin (AP); Ceftazidime (CAZ); Cefotaxime (CTX); Ciprofloxacin (CIP); Streptomycin (ET); Gentamicin (GN); Kanamycin (KN); Netilmycin (NET); Sulfamethoxazole/Trimethoprim (SFT); Tobramycin (TB); Ticarcillin/Clavulanic acid (TIC); Tetracycline (TT) Units - NICU* (neonatal intensive care unit); AICU (adult intensive care unit); BN (nursery); PED (pediatric); GM (general medicine); NPH (nephrology); PN (pulmonary); CV (cardiovascular); END (endocrinology); GS (general surgery); ONC (oncology); THOR (thoracic); ORT (orthopedic); NEU (neurology); UNK (unknown).

\section{DISCUSSION}

Many reports have documented the ubiquitous nature of Acinetobacter spp, opportunistic pathogens frequently implicated in epidemics of hospital infections ${ }^{1,4,14}$. Differentiate epidemic strains from numerous incidental strains found in hospital environment require a precise discrimination among strains within the species.
Among a variety of methods proposed for strain typing, we used biotyping, serotyping and ribotyping to evaluate the spreading of $A$. baumannii in medical care units. As previously reported ${ }^{8}$, biotyping proved to be an easy and appropriated method for screening strains. This method differentiated our 76 strains into six categories with predominance of biotypes 2, 6 and 9 which were already reported as frequently recovered from clinical specimens ${ }^{6,8,19,29}$. Heterogeneity of 
strains of same biotype was further identified with serotyping. Although the great majority of biotype 2 strains were associated with serotypes $\mathrm{O} 29$ and $\mathrm{O} 4$, other three more serotypes were also identified. The same observation was made on the biotype 6 strains which were associated with six different serotypes with the predominance of the biotype 6/ serotype $\mathrm{O} 13$ association. OLIVEIRA et al. ${ }^{19}$, showed that strains of $A$. baumannii belonging to biotype 2/serotype $\mathrm{O} 29$ as well as strains of biotype 6/serotype $\mathrm{O} 13$ were predominant among strains isolated both from inpatients and outpatients of two hospitals in São Paulo, Brazil. It is worth noting that serotype $\mathrm{O} 29$ was recently identified among Brazilian strains as one of the prevalent serotypes ${ }^{19,29}$. Although rarely applied ${ }^{19,28,29}$ serotyping in combination with other methods can be useful for epidemiological studies.

Ribotyping has been used as a taxonomic tool particularly to differentiate strains of Acinetobacter calcoaceticus-Acinetobacter baumannii complex as well as in the differentiation of strains implicated in outbreaks ${ }^{10,11,21}$. In this study ribotyping was used as an additional method to allocate phenotypically defined strains to a given clone. Clone 2:029:A strains were isolated in 10 of 15 studied units and were mainly from adults. Another widely disseminated clone was 6:O13:B (in 9 of 15 evaluated units), and such strains were also from adults. On the other hand, strains belonging to the clone 2:O4:A were closely related to infants. Among 8 strains of this clone, 6 were from neonates and one from a one-year-old aged infant. As previously reported neonates represent an important group of patients susceptible to the acquisition of bacteremia by Acinetobacter ${ }^{18,22}$. Among 76 studied strains, 15 were from neonates, four of them with bacteremia. Interestingly, whereas all strains recovered during 1993 in neonatal intensive care unit, nursery and pediatric unit, belonged to the same clone 2:O4:A, in 1994, distinct clones (2:NT:A; 6:O19:E and 9:Od:Rd) were detected in these units, probably due to the introduction of new strains from the community by the newly admitted patients.

The wide distribution of some clones in several wards suggests that limited outbreaks coexisted during 1993 and 1994. The high antimicrobial multi-resistance patterns exhibited by these strains with epidemic potential probably contributed to their spread despite the control measures. On the other hand many other clones, although with limited potential of dissemination and sporadically isolated in some wards could represent a serious challenge to infection control because of their multiresistance. Which characteristics of epidemic strains are associated with the ability to disseminate through the wards and to colonize or infect a particular host remain to be investigated.

Hospital equipment and hands of hospital staff have been reported as reservoirs of Acinetobacter spp, but often the true source of infection cannot be traced, because of its ubiquitous nature. Moreover, SEIFERT et $a l .{ }^{25}$, documented that the most frequent species associated with hospital infections are rarely recovered from human skin. BOUVET \& GRIMONT $^{6}$ also reported that while patients were infected with $A$. baumannii, species other than $A$. baumannii were recovered from hands of nurses of the same ward. Therefore to explain the introduction of new clones such as 6:O13:B, at the end of 1993 in the hospital, we may postulate the possibility that these strains circulate in the community and once introduced into the hospital setting with the admission of a patient they are selected in hospital environment probably through selective antibiotic pressure or other still unknown epidemiological factors. The widespread distribution of these strains in the wards is probably associated with their ability to survive for long periods of time on dry surfaces which favors transmission between patients via inanimate hospital materials ${ }^{15,30}$. Continuous hospital epidemiological investigations including a complete characterization of nosocomial strains are essential to implement control measures of hospital infections.

\section{RESUMO}

\section{Biotipagem, sorotipagem e ribotipagem na avaliação epidemiológica de $A$. baumannii em unidades hospitalares, Sorocaba, São Paulo, Brasil}

Foi avaliada a disseminação, durante um período de dois anos, de cepas de Acinetobacter baumannii em diferentes unidades de um hospital de Sorocaba, São Paulo.Usando as técnicas de biotipagem, sorotipagem e ribotipagem, as 76 cepas isoladas no período 1993-94, foram diferenciadas em 27 distintos clones. Dois clones, 2:O4:A (biotipo:sorotipo:ribotipo) e 2:O29:A predominaram, em 1993, entre as cepas disseminadas nas várias unidades. Observou-se no final de 1993, a introdução de um novo clone, 6:O13:B e a sua predominância em 1994. Entre as 15 cepas isoladas de recém nascidos, 6 (40\%) pertenciam ao mesmo clone, 2:O4:A . A maioria das cepas desse clone foram isoladas da unidade de terapia intensiva neonatal, de berçário e de unidades pediátricas. Quanto à resistência aos agentes antimicrobianos, todas as cepas foram sensíveis à polimixina B e ao imipenen. Em 1993, 66,7\% das cepas eram multi-resistentes (resistentes de 4 a 12 dos 15 antimicrobianos testados), enquanto que, em 1994, 84,8\% das 46 cepas isoladas foram multi-resistentes a mais de 4 e até a 12 drogas.

\section{REFERENCES}

1. AL-KHOJA, M.S. \& DARREL, J.H. - The skin as a source of Acinetobacter and Moraxella species occurring in blood cultures. J. clin. Path., 32: 497-499, 1979.

2. BECK-SAGUÉ, C.M.; JARVIS, W.R.; BROOK, J.H. et al. - Epidemic bacteremia due to Acinetobacter baumannii in five intensive care units. Amer. J. Epidem., 132: 723$733,1990$.

3. BERGONE-BÉRÉZIN, E. \& JOLY-GUILLOU, M.L. - Hospital infections with Acinetobacter spp: an increasing problem. J. Hosp. Infect., 18 (suppl. A): 250-255, 1991.

4. BIENDO, M.; LAURANS, G.; LEFEBVRE, J.F.; DAOUDI, F. \& EB, F. - Epidemiological study of an Acinetobacter baumannii outbreak by using a combination of antibiotyping and ribotyping. J. clin. Microbiol., 37: 2170-2175, 1999.

5. BOUVET, P.J.M. \& GRIMONT, P.A.D. - Taxonomy of the genus Acinetobacter with the recognition of Acinetobacter baumannii sp.nov., Acinetobacter haemolyticus sp.nov., Acinetobacter johnsonii sp.nov., and Acinetobacter juni sp.nov. and emended descriptions of Acinetobacter calcoaceticus and Acinetobacter lwoffii. Int. J. syst. Bact., 36: 228-240, 1986.

6. BOUVET, P.J.M. \& GRIMONT, P.A.D. - Identification and biotyping of clinical isolates of Acinetobacter. Ann. Inst. Pasteur Microbiol., 138: 569-578, 1987.

7. BOUVET, P.J.M. \& JEANJEAN, S. - Delineation of new proteolytic genomic species in the genus Acinetobacter. Res. Microbiol., 140: 291-299, 1989.

8. BOUVET, P.J.M.; JEANJEAN, S.; VIEU, J.F. \& DIJKSHOORN, L. - Species, biotype, and bacteriophage type determinations compared with cell envelope protein profiles for typing Acinetobacter strains. J. clin. Microbiol., 28: 170-176, 1990. 


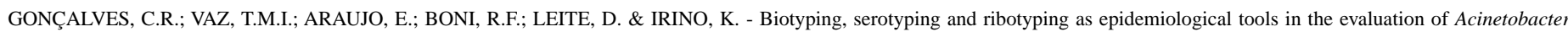
baumannii dissemination in hospital units, Sorocaba, São Paulo, Brazil. Rev. Inst. Med. trop. S. Paulo, 42(5): 277-282, 2000.

9. BRENNER, D.J.; McWHORTER, A.C.; KNUTSON, J.K. \& STEIGERWALT, A.G. Escherichia vulneris: a new species of Enterobacteriaceae asssociated with human wounds. J. clin. Microbiol., 15: 1133-1140, 1982.

10. DIJKSHOORN, L.; AUCKEN, H.; GERNER-SMIDT, P. et al. - Comparison of outbreak and non-outbreak Acinetobacter baumannii strains by genotypic and phenotypic methods. J. clin. Microbiol., 34: 1519-1525, 1996.

11. GERNER-SMIDT, P. - Ribotyping of the Acinetobacter calcoaceticus-Acinetobacter baumannii complex. J. clin. Microbiol., 30: 2680-2685, 1992.

12. GERNER-SMIDT, P. - Acinetobacter: epidemiological and taxonomic aspects. Acta path. microbiol. immunol. scand., 102 (suppl. 47): 1-41, 1994.

13. GO, E.S.; URBAN, C.; BURNS, J. et al. - Clinical and molecular epidemiology of Acinetobacter infections sensitive only to polymyxin B and sulbactam. Lancet, 344: 1329-1332, 1994

14. GUENTHNER, S.H.; HENDLEY, J.O. \& WENZEL, R.P. - Gram-negative bacilli as nontransient flora on the hands of hospital personnel. J. clin. Microbiol., 25: 488-490, 1987.

15. JAWAD, A.; SEIFERT, H.; SNELliNG, A.M.; HERITAGE, J. \& HAWKEY, P.M. Survival of Acinetobacter baumannii on dry surfaces: comparison of outbreak and sporadic isolates. J. clin. Microbiol., 36: 1938-1941, 1998.

16. LORTHOLARY, O.; FAGON, J.Y.; HOI, A.B. et al. - Nosocomial acquisition of multiresistant Acinetobacter baumannii: risk factors and prognosis. Clin. infect. Dis., 20: 790-796, 1995.

17. NATIONAL COMMITTEE FOR CLINICAL LABORATORY STANDARDS Peformance standards for antimicrobial susceptibility testing. 6. ed. Villla Nova, PA., 1997. (Approved Standard M2-A6).

18. NG, P.C.; HERRINGTON, R.A.; BEANE, C.A.; GHONEIM, A.T. \& DEAR, P.R. - An outbreak of Acinetobacter septicaemia in a neonatal intensive care unit. J. Hosp. Infect., 14: 363-368, 1989.

19. OLIVEIRA, M.G.; IRINO, K.; VAZ, T.M.I.; GONÇALVES, C.R. \& LEVY, C.E. Biotypes, serovars and antimicrobial resistance patterns of Acinetobacter baumannii clinical isolates. Zbl. Bakt., 284: 550-558, 1996.

20. POPOVIC, T.; BOPP, C.A.; OLSVIK, O. \& WACHSMUTH, K. - Epidemiologic application of a standardized ribotype scheme for Vibrio cholerae O1. J. clin. Microbiol., 31: 2474-2482, 1993.
21. RATTO, P.; SORDELLI, D.O.; ABELEIRA, E.; TORRERO, M. \& CATALANO, M. Molecular typing of Acinetobacter baumannii-Acinetobacter calcoaceticus complex isolates from endemic and epidemic nosocomial infections. Epidem. Infect., 114 123-132, 1995.

22. REGEV, R.; DOLFIN, T.; ZELIG, T.; GIVONI, S. \& WOLACH, B. - Acinetobacter septicemia: a threat to neonates? Special aspects in a neonatal intensive care unit. Infection, 21: 394-396, 1993.

23. SEIFERT, H.; BAGINSKI, A.; SCHULZE, A. \& PULVERER, G. - Antimicrobial susceptibility of Acinetobacter species. Antimicrob. Agents Chemother., 37: 750753, 1993.

24. SEIFERT, H.; STRATE, A. \& PULVERER, G. - Nosocomial bacteremia due to Acinetobacter baumannii: clinical features, epidemiology and predictors of mortality. Medicine (Baltimore), 74: 340-349, 1995.

25. SEIFERT, H.; DIJKSHOORN, L.; GERNER-SMIDT, P. et al - Distribution of Acinetobacter species on human skin: comparison of phenotypic and genotypic identification methods. J. clin. Microbiol., 35: 2819-2825, 1997.

26. STONE, J.W. \& DAS, B.C. - Investigation of an outbreak of infection with Acinetobacter calcoaceticus in a special care baby unit. J. Hosp. Infect., 7: 42-48, 1986.

27. TJERNBERG, I. \& URSING, J. - Clinical strains of Acinetobacter classified by DNA/ DNA hybridization. Acta path. microbiol. immunol. scand., 97: 596-605, 1989.

28. TRAUB, W.H. - Acinetobacter baumannii serotyping for delineation of outbreaks of nosocomial cross-infection. J. clin. Microbiol., 27: 2713-2716, 1989.

29. VAZ, T.M.I.; GONÇALVES, C.R.; GHILARDI, A.C.R et al. - Acinetobacter species in clinical specimens: biotypes and serotypes of Acinetobacter baumannii strains isolated in São Paulo, Brazil. Rev. Microbiol. (S. Paulo), 27: 116-121, 1996.

30. WENDT, C.; DIETZE, B.; DIETZ, E. \& RUDEN, H. - Survival of Acinetobacter baumannii on dry surfaces. J. clin. Microbiol., 35: 1394-1397, 1997.

31. WOOD, C.A. \& REBOLI, A.C. - Infections caused by imipenem-resistant Acinetobacter calcoaceticus biotype anitratus. J. infect. Dis., 168: 1602-1603, 1993.

Received: 30 March 2000

Accepted : 08 May 2000 